\title{
A new heterozygous mutation (L338N) in the human Gsa (GNAS1) gene as a cause for congenital hypothyroidism in Albright's hereditary osteodystrophy
}

\author{
Joachim Pohlenz, Wiebke Ahrens ${ }^{1}$ and Olaf Hiort ${ }^{1}$ \\ Children's Hospital of the Johannes Gutenberg-University, Mainz, Germany and ${ }^{1}$ Department of Pediatrics, University of Lübeck, Germany \\ (Correspondence should be addressed to J Pohlenz, Children's Hospital of the Johannes Gutenberg-University of Mainz, Langenbeckstrasse 1 , \\ D-55101 Mainz, Germany; Email: pohlenz@mail.uni-mainz.de or pohlenz@kinder.klinik.uni-mainz.de)
}

\begin{abstract}
Objective: To identify the molecular defect by which psychomotor retardation is caused in two brothers with congenital hypothyroidism who received adequate treatment with L-thyroxine.

Case report: A six-year-old boy presented with psychomotor retardation and congenital primary hypothyroidism $(\mathrm{CH})$. The patient had a normal blood thyrotrophin (TSH) level on neonatal screening, but low total serum thyroxine and triiodothyronine concentrations prompting thyroid hormone substitution shortly after birth. Nevertheless, psychomotor development was retarded and the patient underwent further investigation. Typical features of Albright's hereditary osteodystrophy (AHO) such as round face, obesity, and shortened 1st, 4th and 5th metacarpals were found. Methods and results: Further investigation confirmed AHO with pseudohypoparathyroidism (PHP) type Ia. The boy had a mild resistance to parathyroid hormone and a reduced adenylyl cyclase stimulating protein $(\mathrm{Gs} \alpha)$ activity in erythrocytes. DNA analysis detected a new heterozygous mutation (L338N) in the Gs $\alpha$ protein (GNAS1) gene. This mutation was also present in the patient's brother who had similar features and was also treated with thyroid hormone because of $\mathrm{CH}$, and in the phenotypically normal-looking mother who had a normal calcium metabolism but a reduced Gs $\alpha$ protein activity in erythrocytes suggestive of pseudopseudohypoparathyroidism.

Conclusion: In patients with $\mathrm{CH}$, in whom the neurological outcome is poor even under adequate thyroid hormone substitution, PHP Ia may be suspected, especially when symptoms of AHO are present.
\end{abstract}

European Journal of Endocrinology $148463-468$

\section{Introduction}

Congenital hypothyroidism $(\mathrm{CH})$ occurs in 1 of 4000 births and is caused, in decreasing order of frequency, by thyroid dysgenesis, thyroid dyshormonogenesis, defects of thyrotrophin (TSH) or TSH-receptor, or hypothalamic-pituitary deficiency (1). Due to screening programs and early diagnosis, treatment of affected individuals is usually started within the first two weeks of life. With adequate therapy, growth and mental development proceed normally in infants with $\mathrm{CH}$ (1). However, in some patients with $\mathrm{CH}$ the neurological outcome is poor even under adequate hormone substitution. In such patients the retarded mental development may be related to other defects.

Pseudohypoparathyroidism (PHP) is biochemically characterized by hypocalcemia and hyperphosphatemia in association with an increased secretion of parathyroid hormone (PTH) due to target tissue unresponsiveness to PTH (2). PHP type Ia represents one variant of this condition in which patients are not only resistant to PTH but also to other hormones that bind to receptors coupled to stimulatory G protein (Gs) to activate adenylyl cyclase (3). In addition, these patients have characteristic features of Albright's hereditary osteodystrophy (AHO) which are a round face, brachymetacarpy, short stature, obesity, mental retardation and subcutaneous calcifications (2). PHP Ia and AHO are caused by a reduced activity of the adenylyl cyclase stimulating protein $(\mathrm{Gs} \alpha)$. The gene encoding this protein (GNAS1) is located on chromosome 20q13.2-13.3. Heterozygous inactivating GNAS1 mutations have been identified in patients with AHO and PHP (4), following an autosomal-dominant trait.

We studied a six-year-old boy and his eight-year-old brother with $\mathrm{CH}$, who developed mental retardation 
despite adequate treatment with L-thyroxine $\left(\mathrm{L}-\mathrm{T}_{4}\right)$ started shortly after birth. Both boys displayed features of AHO. PHP Ia was suspected even though serum PTH was only slightly elevated in association with a normal serum calcium concentration. This diagnosis was confirmed in both boys by a decreased Gs $\alpha$ subunit protein activity in erythrocyte membranes and identification of a novel heterozygous mutation in codon 338 (L338N) of their GNAS1 genes.

\section{Subjects and methods}

\section{Patients}

The propositus was the second born to unrelated parents at term and after a normal pregnancy. His birth weight was $3325 \mathrm{~g}$ and his length was $49 \mathrm{~cm}$. Because his brother was treated for congenital hypothyroidism, thyroid function tests were performed two days after birth. They revealed a normal serum TSH of $9.0 \mathrm{mU} / \mathrm{l}$ (normal range 3.0-18 mU/l) but low blood thyroxine $\left(\mathrm{T}_{4}\right)$ and triiodothyronine $\left(\mathrm{T}_{3}\right)$ concentrations. Therefore treatment with $\mathrm{L}-\mathrm{T}_{4}$ was initiated. Six weeks later respiratory problems became apparent. Tracheomalacia was diagnosed and the boy underwent surgery at the age of 3 months. The boy continued to receive $\mathrm{L}^{-\mathrm{T}_{4}}$ in doses that were adjusted for his age and weight. He was tested repeatedly and always had thyroid function tests within the normal range. Development proceeded slowly and by the age of 2 years psychomotor retardation was evident. He was also found to have impaired conductive hearing. Further diagnostic tests, including electroencephalography and cranial computer tomography, failed to identify the underlying defect. Interestingly, the brother, who also received thyroid hormone replacement therapy, had a very similar phenotype so that an inherited disease was suspected. Review of his medical history revealed a normal neonatal screening result for $\mathrm{CH}$ with a TSH level below $15 \mathrm{mU} / \mathrm{l}$. Prolonged jaundice prompted further evaluation at the age of 2 months. His serum TSH level was slightly elevated and his total $\mathrm{T}_{3}$ and $\mathrm{T}_{4}$ levels were below the lower limits of normal so that thyroid hormone substitution was started and adjusted subsequently for his age and weight.

At the age of 6 years the propositus and his eightyear-old brother presented to our outpatient clinic. The children appeared physically and mentally retarded. Both were obese with round faces and had broad necks and brachydactyly. Their thyroid glands were normal in size, a finding confirmed by ultrasound. Laboratory tests revealed a suppressed serum TSH associated with high levels of total and free $\mathrm{T}_{4}$, which can be explained by the high doses of $\mathrm{L}^{-\mathrm{T}_{4}}$ given as replacement therapy (index patient $\left(\mathrm{II}_{2}\right)$ $150 \mu \mathrm{g} \mathrm{L}^{-} \mathrm{T}_{4}$, brother $\left(\mathrm{II}_{1}\right) 200 \mu \mathrm{g} \mathrm{L}-\mathrm{T}_{4}$ daily). Thyroid antibodies were negative. Furthermore, analysis of the calcium metabolism showed normal phosphate and calcium but slightly elevated PTH levels in both boys. The radiographs of the left hand of both boys showed shortened 1st, 4th and 5th metacarpals.

Following discontinuation of $\mathrm{L}^{-} \mathrm{T}_{4}$ treatment serum TSH levels rose to 16 and $23.8 \mathrm{mU} / \mathrm{l}$ in the propositus and in his older brother respectively, while serum free (f) $\mathrm{T}_{4}$ and $\mathrm{fT}_{3}$ remained well within the normal range. Values were 1.25 and $1.65 \mathrm{ng} / \mathrm{dl}$ for $\mathrm{fT}_{4}$ and 3.31 and $2.67 \mathrm{pg} / \mathrm{ml}$ for $\mathrm{fT}_{3}$ (for normal ranges see Fig. 1). Furthermore, administration of thyrotrophin-releasing hormone (TRH) increased their serum TSH at $30 \mathrm{~min}$ to peak values of 30.1 and $44.2 \mathrm{mU} / \mathrm{l}$ in the propositus and in his brother respectively, with a further increase in the $\mathrm{fT}_{3}$ values by $12-33 \%$ above baseline.

Laboratory tests carried out on all members of the family are shown in Fig. 1. Determination of Gs $\alpha$ protein activity in erythrocyte membranes was reduced in both boys $(50.9 \%$ and $48.7 \%)$ and in the mother (45.5\%) compared with healthy individuals suggesting a defect in the Gs $\alpha$ protein. To characterize the underlying molecular defect, the GNAS1 gene was sequenced. All family members gave informed consent to participate in the study.

\section{Clinical tests}

Serum TSH, total $T_{4}$, total $\mathrm{T}_{3}, \mathrm{fT}_{4}$ and $\mathrm{fT}_{3}$ concentrations were measured by chemiluminescent immunoassays (Chiron Diagnostics, Fernwald, Germany). For the measurement of PTH an Immulite-Assay (DPC-Biermann, Bad Nauheim, Germany) was used.

\section{Gs $\alpha$ protein activity}

The activity of the Gs $\alpha$ protein in erythrocyte membranes was analysed in heparinized blood samples as described previously (5). Briefly, after solubilization of the Gs protein from the patients' erythrocyte membranes and activation with GTP $\gamma \mathrm{S}$, cAMP generation was measured by radioimmunoassay (Immuno Biological Laboratories, Hamburg, Germany) using adenylyl cyclase from turkey red cell membranes in the presence of ATP. Results obtained in triplicate were expressed as per cent of the mean of healthy controls (normal range 85-115\%).

\section{Molecular studies}

Genomic deoxyribonucleic acid (DNA) was extracted from circulating white blood cells of all family members and was used for amplification of exons 2-13 of the GNAS1 gene. The sequences of oligonucleotide primers and conditions for the polymerase chain reactions (PCR) have been described previously (6). Total ribonucleic acid (RNA) was extracted from cultured skin fibroblasts of the index patient using the phenol/ guanidine isothiocyanate method (Trizol; Gibco BRL, Carlsruhe, Germany). The first complementary DNA (cDNA) strand that was used for PCR was synthesized 


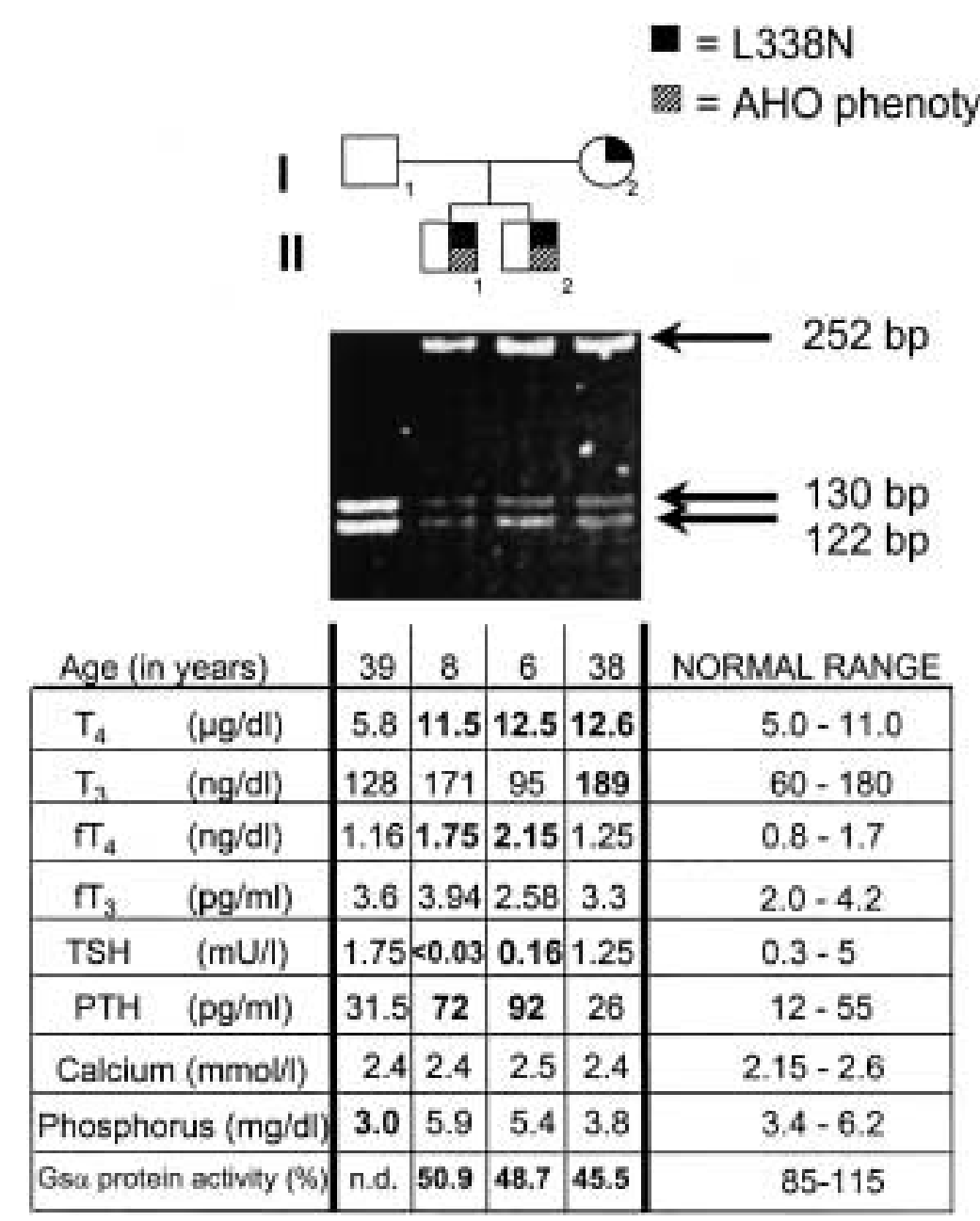

Figure 1 Pedigree of the family, thyroid function tests and results of DNA analyses. The AHO phenotype is indicated by hatched symbols. Black boxes show the presence of the heterozygous mutation, L338N. Figures in bold represent means outside the normal range. All data are aligned to the subjects' symbols on the pedigree. The mutation, L338N, removes a restriction site for Rsal. Therefore, exon 12 was amplified from genomic DNA from all family members. The PCR products were then digested with Rsal, electrophoresed on a $10 \%$ polyacrylamide gel and, after exposure to ethidium bromide, visualized under UV-light. In normal individuals the amplified PCR product of $252 \mathrm{bp}$ is cut into a $130 \mathrm{bp}$ and a $122 \mathrm{bp}$ fragment. In the mutant allele which carries L338N the amplified band remains uncut.

with avian myeloblastosis virus reverse transcriptase (Promega, Mannheim, Germany) and an oligo-DT primer.

The PCR amplified products were purified and sequenced directly using an automated fluorescencebased sequencer (ABI 377, Perkin-Elmer, Weiterstadt, Germany).

The mutation L338N which is located in exon 12 of the GNAS1 gene removes a restriction site for RsaI. Genomic DNA was used to amplify exon 12 of all family members. The PCR products were then digested with RsaI, electrophoresed on a $10 \%$ polyacrylamide gel and after exposure to ethidium bromide, visualized under UV-light. In normal individuals the amplified PCR product of $252 \mathrm{bp}$ is cut into a $130 \mathrm{bp}$ and a $122 \mathrm{bp}$ fragment. In the mutant allele which carries L338N the amplified band remains uncut.

\section{Results}

Direct sequencing of exons 2-13 of the GNAS1 gene of the propositus using genomic DNA revealed a heterozygous transition of the normal guanine at nucleotide 1082 (according to the published sequence in Genbank Acc. No. NM000516) to a mutant cytosine $(\mathrm{AAG} \rightarrow \mathrm{AAC})$. The same result was obtained by sequencing fibroblast cDNA. This mutation results in the replacement of the normal lysine with an asparagine in codon 338 (L338N) (Fig. 2).

The pedigree and genotyping analysis of all family members are shown in Fig. 1. The mutation removes a restriction site for RsaI allowing verification and rapid screening for the mutation by digestion of the amplification product. The result shows that the propositus is indeed heterozygous for L338N (Fig. 1) 


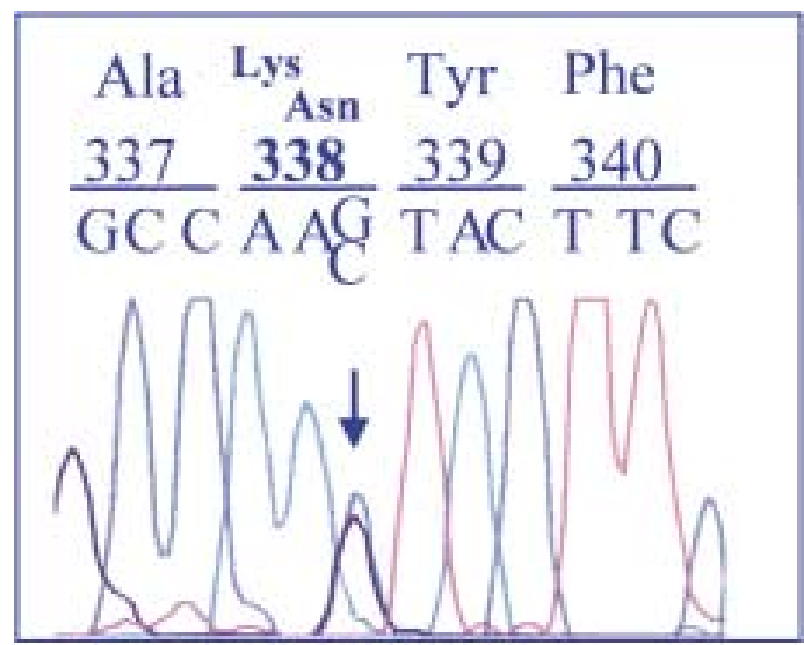

Figure 2 Automated fluorescence based on direct sequencing of the patient's GNAS1 gene from genomic DNA. Note the substitution of the normal guanine $(G)$ with a mutant cytosine $(C)$ in codon 338 (AAG $\rightarrow$ AAC) (arrow). This mutation results in the replacement of the normal lysine with an asparagine (L338N). The patient is heterozygous for the mutation since mutant $C$ and normal $\mathrm{G}$ are present in position 1082.

since his DNA fragment is only partially digested while that of the unaffected father is fully digested. His affected brother and his mother, who also has a reduced Gs $\alpha$ protein activity $(45.5 \%)$ but normal calcium metabolism and no brachymetacarpy or other obvious signs of AHO are heterozygous for the mutation.

\section{Discussion}

This study demonstrates that patients with $\mathrm{CH}$ and poor mental development despite sufficient thyroid hormone substitution therapy should be considered to have a deficiency of Gs $\alpha$ protein activity, especially when they display symptoms of AHO or PHP. In our patients the diagnosis of PHP Ia was delayed because neither boy developed hypocalcemia which could have led to the correct diagnosis earlier. It is known that patients with PHP Ia have resistance to other hormones that stimulate cAMP production in target cells via the Gs $\alpha$ pathway. This explains the elevated serum TSH levels in such patients (4). However, it is unclear whether the resistance to TSH results in true hypothyroidism and whether these patients benefit from treatment with thyroid hormone.

On neonatal screening both boys had normal TSH concentrations which is in contrast to the observation made by others who found elevated TSH levels in individuals with PHP Ia at birth $(7-10)$. When thyroid hormone substitution was initiated in the older boy, he had low peripheral thyroid hormone levels in association with an elevated serum TSH concentration indicating true primary hypothyroidism. The younger boy was treated with thyroid hormone because it was known that his older brother had hypothyroidism. He had allegedly a normal serum TSH but low peripheral thyroid hormone levels when thyroid hormone substitution was started. However, when thyroid hormone was stopped in both boys for a period of two weeks, serum thyroid hormone levels were still within the normal range whereas the TSH levels were elevated (see Results). The ability to further respond to TRH and for the thyroid gland to respond to TSH by an increase in serum $\mathrm{T}_{3}$, indicates that both brothers had partial resistance to TSH rather than primary thyroid gland failure.

This finding prompted us to compare our patients with others with PHP Ia and mutation in the GNAS1 gene and resistance to TSH or who were considered to be hypothyroid $(5,6,10-22)$. Of the 13 patients who were reported to have elevated serum TSH concentrations $(10,11,13-15,17-19,22,23)$ eight were treated with thyroid hormone $(10,13,15$, $17,19)$. Four had low thyroid hormone levels (10, 13, 14, 17), whereas in four other individuals the levels were normal $(11,15,22,23)$. In the remaining five cases thyroid hormone levels were not mentioned $(18,19)$. Furthermore, in the vast majority of the published cases no detailed information regarding thyroid function tests and thyroid hormone treatment is given. Thus, it is uncertain how many patients with PHP Ia and known GNAS1 mutation had hyperthyrotrophinemia. Consequently, a conclusion with regard to a beneficial effect from thyroid hormone substitution cannot be drawn.

It is not known why patients with PHP Ia are mentally retarded. The decreased Gs $\alpha$ protein activity which leads to a reduced cAMP concentration may explain why mental deficiency is associated with Gs protein defects (24). Because serum $\mathrm{T}_{3}$ and $\mathrm{T}_{4}$ concentrations were within the normal ranges in both boys and thyroid hormone substitution was initiated immediately, hypothyroidism is unlikely to be the cause of the delayed mental development. This observation would be supported if individuals with pseudopseudohypoparathyroidism (PPHP) who have AHO and Gs $\alpha$ protein deficiency but no hormonal resistance frequently developed psychomotor retardation. Unfortunately, the diagnosis of PHP versus PPHP is not clearly established in many hitherto reported cases and the description of the mental development of individuals with PPHP is limited.

Defects in the Gs $\alpha$ protein may result in either loss or gain of endocrine function. So far, 52 different loss-offunction mutations have been reported $(4-6,10-23$, 25-35) in more than 70 affected individuals. A complete updated list of all known mutations is available online (http:/mammary.nih.gov.aho/). In the present study a missense mutation in codon 338 of exon 12 of the GNAS1 gene was identified which to our 
knowledge has not previously been described. Since the Gs $\alpha$ protein activity was severely reduced in erythrocyte membranes of both boys we demonstrate that the mutant protein is defective. It is conceivable that substitution of a leucine which has a nonpolar side chain, by an asparagine with an uncharged polar side chain could result in a conformational change leading to a defective protein. However, based on our studies we cannot predict the precise mechanism by which loss-offunction is caused by L338N. Further studies are needed to exclude a targeting defect. Furthermore, we have no explanation for the absence of mental retardation in the mother despite a similar degree of impaired Gs $\alpha$ function.

In conclusion, Gs $\alpha$ protein defects can cause $\mathrm{CH}$. This diagnosis should be considered in children with hypothyroidism that have a poor mental development despite adequate treatment with thyroid hormone and who display features of AHO. Whether these patients benefit from thyroid hormone substitution remains unclear although our patients did not. Elevated TSH levels simply reflect a defect in TSH signaling and do not necessarily indicate true hypothyroidism. Thyroid hormone levels should be monitored in these patients.

\section{Acknowledgements}

We thank the support of Serono Pharma (Munich, Germany). We also thank Prof. Samuel Refetoff (University of Chicago) for discussion and critical review of the manuscript. This work was presented in part at the 39th Annual Meeting of the European Society for Pediatric Endocrinology in Brussels, Belgium, 17-19 September 2000.

\section{References}

1 Fisher DA. Disorders of the thyroid in the newborn and infant. In Pediatric Endocrinology, edn 1, ch. 4, pp 51-70. Ed. MA Sperling. Philadelphia: WB Saunders, 1996.

2 Albright F, Burnett C, Smith P \& Parson P. Pseudohypoparathyroidism - an example of 'Seabright-Bantam syndrome'. Endocrinology $194230922-932$.

3 Levine MA, Downs JRW, Moses AM, Breslau NA, Marx SJ, Lasker RD et al. Resistance to multiple hormones in patients with pseudohypoparathyroidism. American Journal of Medicine $198374545-556$.

4 Weinstein LS, Yu S, Warner DR \& Liu J. Endocrine manifestations of stimulatory $\mathrm{G}$ protein alpha-subunit mutations and the role of genomic imprinting. Endocrine Reviews 200122 675-705.

5 Ahrens W, Hiort O, Staedt P, Kirschner T, Marschke C \& Kruse K. Analysis of the GNAS1 gene in Albright's hereditary osteodystrophy. Journal of Clinical Endocrinology and Metabolism $2001864630-4634$.

6 Miric A, Vechio JD \& Levine MA. Heterogeneous mutations in the gene encoding the alpha-subunit of the stimulatory $G$ protein of adenylyl cyclase in Albright hereditary osteodystrophy. Journal of Clinical Endocrinology and Metabolism $1993 \mathbf{7 6}$ $1560-1568$.
7 Weisman Y, Golander A, Spirer Z \& Farfel Z. Pseudohypoparathyroidism type 1a presenting as congenital hypothyroidism. Journal of Pediatrics $1985 \mathbf{1 0 7} 413-415$.

8 Levine MA, Jap TS \& Hung W. Infantile hypothyroidism in two sibs: an unusual presentation of pseudohypoparathyroidism type Ia. Journal of Pediatrics 1985 107 919-922.

9 Yokoro S, Matsuo M, Ohtsuka T \& Ohzeki T. Hyperthyrotropinemia in a neonate with normal thyroid hormone levels: the earliest diagnostic clue for pseudohypoparathyroidism. Biology of the Neonate 199058 69-72.

$10 \mathrm{Yu}$ D, Yu S, Schuster V, Kruse K, Clericuzio CL \& Weinstein LS. Identification of two novel deletion mutations within the Gs alpha gene (GNAS1) in Albright hereditary osteodystrophy. Journal of Clinical Endocrinology and Metabolism $1999 \mathbf{8 4}$ 3254-3259.

11 Ishikawa Y, Tajima T, Nakae J, Nagashima T, Satoh K, Okuhara K et al. Two mutations of the Gs alpha gene in two Japanese patients with sporadic pseudohypoparathyroidism type Ia. Journal of Human Genetics $2001 \mathbf{4 6} 426-430$.

12 Nakamoto JM, Sandstrom AT, Brickman AS, Christenson RA \& Van Dop C. Pseudohypoparathyroidism type Ia from maternal but not paternal transmission of a Gs alpha gene mutation. American Journal of Medical Genetics 199877 261-267.

13 Shapira H, Mouallem M, Shapiro MS, Weisman Y \& Farfel Z. Pseudohypoparathyroidism type Ia: two new heterozygous frameshift mutations in exons 5 and 10 of the Gs alpha gene. Human Genetics 199697 73-75.

14 Farfel Z, Iiri T, Shapira H, Roitman A, Mouallem M \& Bourne HR. Pseudohypoparathyroidism, a novel mutation in the betagammacontact region of Gs alpha impairs receptor stimulation. Journal of Biological Chemistry 1996271 19653-19655.

15 Yokoyama M, Takeda K, Iyota K, Okabayashi T \& Hashimoto K. A 4-base pair deletion mutation of Gs alpha gene in a Japanese patient with pseudohypoparathyroidism. Journal of Endocrinological Investigation $199619236-241$.

16 Patten JL, Johns DR, Valle D, Eil C, Gruppuso PA, Steele G et al. Mutation in the gene encoding the stimulatory $G$ protein of adenylate cyclase in Albright's hereditary osteodystrophy [see comments]. New England Journal of Medicine $1990 \mathbf{3 2 2}$ 1412-1419.

17 Schwindinger WF, Miric A, Zimmerman D \& Levine MA. A novel Gs alpha mutant in a patient with Albright hereditary osteodystrophy uncouples cell surface receptors from adenylyl cyclase. Journal of Biological Chemistry $199426925387-25391$.

18 Fischer JA, Egert F, Werder E \& Born W. An inherited mutation associated with functional deficiency of the alpha-subunit of the guanine nucleotide-binding protein Gs in pseudo- and pseudopseudohypoparathyroidism. Journal of Clinical Endocrinology and Metabolism $1998 \mathbf{8 3} 935-938$.

19 Mantovani G, Romoli R, Weber G, Brunelli V, De Menis E, Beccio S et al. Mutational analysis of GNAS1 in patients with pseudohypoparathyroidism: identification of two novel mutations. Journal of Clinical Endocrinology and Metabolism $2000 \mathbf{8 5}$ 4243-4248.

20 Walden U, Weissortel R, Corria Z, Yu D, Weinstein L, Kruse K et al. Stimulatory guanine nucleotide binding protein subunit 1 mutation in two siblings with pseudohypoparathyroidism type $1 \mathrm{a}$ and mother with pseudopseudohypoparathyroidism. European Journal of Pediatrics 1999158 200-203.

21 Warner DR, Gejman PV, Collins RM \& Weinstein LS. A novel mutation adjacent to the switch III domain of G(S alpha) in a patient with pseudohypoparathyroidism. Molecular Endocrinology $1997111718-1727$.

22 Sobottka SB, Huebner A, Haase M, Ahrens W, Rupprecht E, Schackert HK et al. Albright's hereditary osteodystrophy associated with cerebellar pilocytic astrocytoma: coincidence or genetic relationship? Hormone Research 200155 196-200.

23 Bastida Eizaguirre M, Iturbe Ortiz de Urbina R, Arto Urzaininqui MJ, Ezquerra Larreina R \& Escalada San Martin J. Osteodistrofia 
hereditaria de Albright. Identificacion de una mutacion original en una familia. Anales Espanoles Pediatria 200154 598-600.

24 Farfel Z \& Friedman E. Mental deficiency in pseudohypoparathyroidism type I is associated with Ns-protein deficiency. Annals of Internal Medicine 1986105 197-199.

25 Wilson LC, Oude Luttikhuis ME, Clayton PT, Fraser WD \& Trembath RC. Parental origin of Gs alpha gene mutations in Albright's hereditary osteodystrophy. Journal of Medical Genetics $199431835-839$.

26 Weinstein LS, Gejman PV, Friedman E, Kadowaki T, Collins RM, Gershon ES et al. Mutations of the Gs alpha-subunit gene in Albright's hereditary osteodystrophy detected by denaturing gradient gel electrophoresis. PNAS 199087 8287-8290.

27 Ringel MD, Schwindinger WF \& Levine MA. Clinical implications of genetic defects in $\mathrm{G}$ proteins. The molecular basis of McCuneAlbright syndrome and Albright's hereditary osteodystrophy. Medicine 199675 171-184.

28 Aldred MA \& Trembath RC. Activating and inactivating mutations in the human GNAS1 gene. Human Mutation 2000 $16183-189$.

29 Aldred MA, Bagshaw RJ. Macdermot K, Casson D, Murch SH, Walker-Smith JA et al. Germline mosaicism for a GNAS1 mutation and Albright's hereditary osteodystrophy. Journal of Medical Genetics 200037 E35.

$30 \mathrm{Wu}$ WI, Schwindinger WF, Aparicio LF \& Levine MA. Selective resistance to parathyroid hormone caused by a novel uncoupling mutation in the carboxyl terminus of $\mathrm{G}$ alpha(s). A cause of pseudohypoparathyroidism type Ib. Journal of Biological Chemistry 2001276 165-171.
31 Luttikhuis ME, Wilson LC, Leonard JV \& Trembath RC. Characterization of a de novo 43-bp deletion of the Gs alpha gene (GNAS1) in Albright's hereditary osteodystrophy. Genomics $199421455-457$.

32 Nakamoto JM, Zimmerman D, Jones EA, Loke KY, Siddiq K, Donlan MA et al. Concurrent hormone resistance (pseudohypoparathyroidism type Ia) and hormone independence (testotoxicosis) caused by a unique mutation in the Gas gene. Biochemical and Molecular Medicine 199658 18-24.

33 Warner DR, Weng G, Yu S, Matalon R \& Weinstein LS. A novel mutation in the switch 3 region of Gs alpha in a patient with Albright's hereditary osteodystrophy impairs GDP binding and receptor activation. Journal of Biological Chemistry $1998 \mathbf{2 7 3}$ $23976-23983$

34 Weinstein LS, Gejman PV, de Mazancourt P, American N \& Spiegel AM. A heterozygous 4-bp deletion mutation in the Gs alpha gene (GNAS1) in a patient with Albright's hereditary osteodystrophy. Genomics 199213 1319-1321.

35 de Sanctis L, Romagnolo D, de Sanctis C, Lala R, Olivero M, Di Renzo F et al. Albright's hereditary osteodystrophy (AHO) and pseudohypoparathyroidism: three new mutations and a common deletion in the GNAS1. American Journal of Human Genetics 200067 (Suppl 2) 295 (Abstract).

Received 6 November 2002

Accepted 21 January 2003 